\title{
Triple gastric peptic ulcer perforation
}

\author{
Milan Radojkovic, M.D.,, ${ }^{1}$ Suncica Mihajlovic, M.D., ${ }^{2}$ Miroslav Stojanovic, M.D., ${ }^{1}$ \\ Goran Stanojevic, M.D., ${ }^{1}$ Zoran Damnjanovic, M.D. ${ }^{3}$
}

SerbiaSerbiaSerbia

\begin{abstract}
Patients with advanced or metastatic cancer have compromised nutritional, metabolic, and immune conditions. Nevertheless, little is known about gastroduodenal perforation in cancer patients. Described in the present report is the case of a $4 \mathrm{I}$-year old woman with stage IV recurrent laryngeal cancer, who used homeopathic anticancer therapy and who had triple peptic ulcer perforation (PUP) that required surgical repair. Triple gastric PUP is a rare complication. Self-administration of homeopathic anticancer medication should be strongly discouraged when evidence-based data regarding efficacy and toxicity is lacking.
\end{abstract}

Keywords: Peptic ulcer; perforation.

\section{INTRODUCTION}

Perforation is very often the first clinical presentation of peptic ulcer disease (PUD), occurring in 2-10\% of PUD patients and associated with more than $70 \%$ of PUD patient deaths. ${ }^{[I]}$ The most common perforation site is the anterior wall of the duodenum (60\%), as well as the gastric antrum (20\%) and the lesser curvature (20\%). ${ }^{[2]}$ While perforation is still considered a disorder that primarily affects younger male patients, the average age of patients with peptic ulcer perforation (PUP) has recently been increasing- affecting predominantly females, with current incidence peak of 40-60 years of age. ${ }^{[3,4]}$ Despite the introduction of powerful anti-peptic-ulcer medications, growing experience with Taylor's method, and persistent post-surgery mortality rate, incidence of PUP requiring surgical treatment has remained stable or even increased. ${ }^{[2]}$ Increasing incidences of both PUD and PUP may be due to widespread use of certain drugs such as aspirin, ibuprofen, and other nonsteroidal anti-

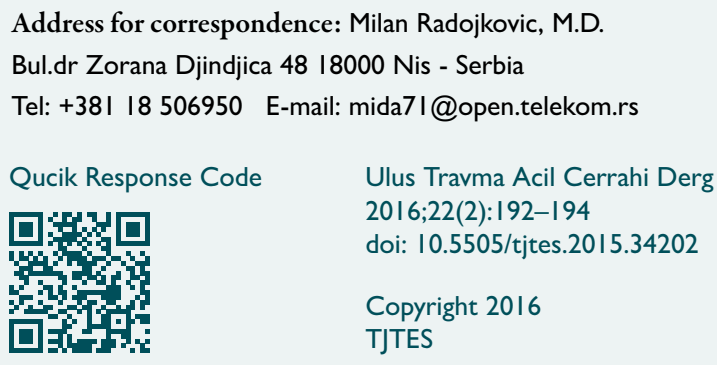

inflammatory drugs. Immunocompromised patients, including those who are stressed, elderly, traumatized, and/or who have chronic disease are at higher risk of both PUD and PUP. Described in the present report is the case of a cancer patient with an unusual form of PUP who had been taking anticancer homeopathic therapy.

\section{CASE REPORT}

A 4l-year old woman presented to the emergency department with sudden, severe epigastric pain that had begun 7 hours prior to admittance. The pain was constant, had progressive intensity, and was spreading to the entire abdomen without accompaniment of vomiting or stool changes. On physical examination, the patient had generalized tenderness with guarding and rigidity. She was very pale, fatigued, and afebrile, with a pulse of $102 \mathrm{bpm}$, blood pressure of 90/60 $\mathrm{mmHg}$, and respiratory rate of 22 breaths per minute. The patient was not able to speak due to present tracheostomy. Her body weight was very low, and she had an overall appearance characteristic of malignant cachexia. Heteroanamnesis revealed that the patient had been diagnosed with stage IV laryngeal (planocellular focally keratinized) cancer 19 months prior, and had undergone total laryngectomy and tracheotomy, as well as radiation therapy (68 Gy in 34 fractions). She had been subsequently diagnosed with recurrent cancer locally infiltrating the hypopharynx, for which she was receiving only symptomatic therapy. In the 3 months prior to 


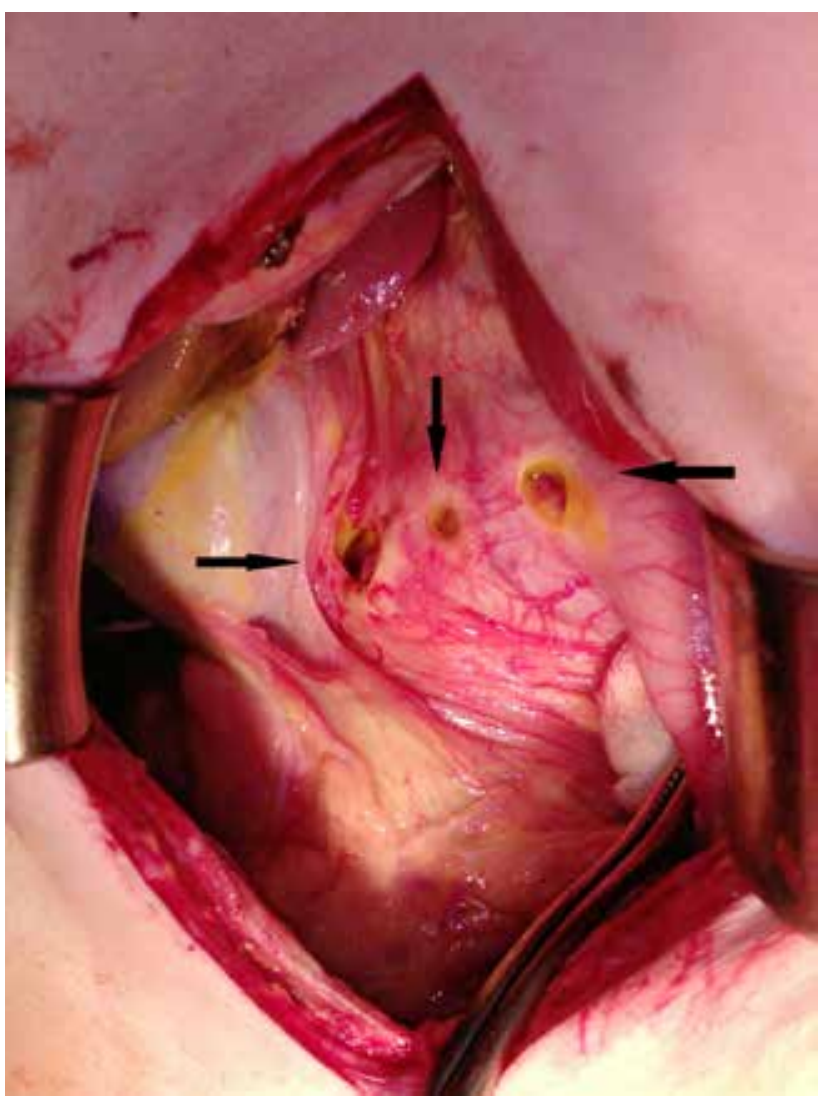

Figure 1. Triple gastric peptic ulcer perforation on the anterior wall of the pyloric region.

admittance, the patient had been self-administering homeopathic anticancer treatment consisting of sublingual intake of 5 drops, every 12 hours, of Vidatox ${ }^{\circledR}$ Homeopático $30 \mathrm{CH}$ (Labiofam, Holguin, Cuba). The drug is produced from 5 protein peptides extracted from the venom of the blue scorpion, Rhopalurus junceus, in a $33 \%$ hydroalcoholic solution. ${ }^{[5]}$

Plain abdominal radiography showed massive pneumoperitoneum. Laboratory studies revealed leukocytosis (16.3×10\%/L) and anemia (hemoglobin of $161 \mathrm{mg} / \mathrm{L}$ ). After brief stabilization, prophylactic antibiotics were administered, and the patient underwent upper midline laparotomy. Intraoperatively, diffuse peritonitis due to triple gastric PUPs, each measuring to 4-6 $\mathrm{mm}$ in diameter, was found on the anterior wall of the pyloric region (Fig. I). Following excision, Heineke-Mikulicz pyloroplasty was performed, as was Kader-Stamm gastrostomy. The abdominal cavity was rinsed, drained, and closed. Postoperative course was uneventful. Histopathological examination of the specimen excluded gastric malignancy and confirmed the peptic nature of the lesions.

\section{DISCUSSION}

Spontaneous gastroduodenal perforation has been reported in patients with non-gastrointestinal (non-Gl) forms of cancer who were administered cytotoxic drugs, corticosteroids, or radiation therapy as primary or adjuvant treat- ment. ${ }^{[6]}$ Serious Gl complications tend to develop in patients with underlying $\mathrm{Gl}$ diseases and/or who receive therapeutic agents with high $\mathrm{Gl}$ toxicity profiles. While double perforations can occur, ${ }^{[7]}$ triple PUP is very rare. Radiotherapy is a well-known risk factor for $\mathrm{Gl}$ perforation due to radiation injuries that involve ischemic tissue changes. ${ }^{[8,9]}$ While the present patient had recurrent disease, it was not localized in the Gl tract; radiotherapy was not directed to the patient's abdomen. With the exception of former heavy smoking with its well-known ulcerogenic effects and psychological stress, the patient had no history of PUD or other chronic Gl disease predisposing her to perforations. The absence of callosity due to chronic inflammatory changes, the hallmark of perforated ulcers, around perforation sites led to the conclusion that perforation was not the result of chronic PUD. Whether these perforations could be induced solely by cigarette toxicity and/or psychological stress may be debatable, especially considering the unusual occurrence of triple PUP and the fact that the patient had quit smoking nearly 2 years earlier. Still, compromised immunity and malnutrition due to malignancy contributed to the intensity of PUD complication. Cancer-induced immunodeficiency and additional, anticancer-therapy-induced immunosuppression affected the gastrointestinal tract, causing loss of gastric acidity, impaired immune response, reduced mucosal integrity, and compromised mucosal regeneration. ${ }^{[10]}$

Chemotherapy has been identified as an important factor, influencing non-favorable, short-term postoperative results in cancer patients with PUP. ${ }^{[1]}$ In addition, the unusual addition of homeopathic medication was present, the active principle of which is venom in water and ethanol. It is stated on the official commercial website of the manufacturer that the homeopathic medication improves quality of life and survival rates of cancer patients, provides pain relief, prevents symptoms produced by cytostatic drugs and ionizing radiation, has antitumoral and antimetastatic effects on solid tumors, and is a non-toxic product with no side effects that can have a synergic or potentiating effect with other conventional anticancer treatment if used simultaneously. ${ }^{[5]}$ The present authors were not able to find evidence-based clinical or experimental reports that investigated features, therapeutic effects, or toxicity of this medication on available internet databases. Compromised immune response could also have allowed for severe Helicobacter pylori infection in the patient, which appears to also have been associated with PUP in up to twothirds of PUD patients. ${ }^{[12]}$

Surgeons should have high suspicion of PUP in cancer patients presenting with severe acute abdominal pain; triple gastric PUP is a rare complication of PUD. Self-administration of homeopathic anticancer medication in the absence of evidence-based data regarding efficacy and toxicity should be strongly discouraged.

Conflict of interest: None declared. 


\section{REFERENCES}

1. Druart ML, Van Hee R, Etienne J, Cadière GB, Gigot JF, Legrand M, et al. Laparoscopic repair of perforated duodenal ulcer. A prospective multicenter clinical trial. Surg Endosc 1997;11:1017-20. CrossRef

2. Zittel TT, Jehle EC, Becker HD. Surgical management of peptic ulcer disease today--indication, technique and outcome. Langenbecks Arch Surg 2000;385:84-96. CrossRef

3. Lunevicius R, Morkevicius M. Management strategies, early results, benefits, and risk factors of laparoscopic repair of perforated peptic ulcer. World J Surg 2005;29:1299-310. CrossRef

4. Imhof M, Epstein S, Ohmann C, Röher HD. Duration of survival after peptic ulcer perforation. World J Surg 2008;32:408-12. CrossRef

5. http://www.labiofam.cu/en/productos/vidatox-30ch.html.

6. Liaw CC, Huang JS, Wang HM, Wang CH. Spontaneous gastroduodenal perforation in patients with cancer receiving chemotherapy and steroids. Report of four cases combining 5-fluorouracil infusion and cisplatin with antiemetics dexamethasone. Cancer 1993;72:1382-5. CrossRef
7. Bertleff MJ, Lange JF. Perforated peptic ulcer disease: a review of history and treatment. Dig Surg 2010;27:161-9. CrossRef

8. Casey EM, Harb W, Bradford D, Bufill J, Nattam S, Patel J, et al. Randomized, double-blinded, multicenter, phase II study of pemetrexed, carboplatin, and bevacizumab with enzastaurin or placebo in chemonaive patients with stage IIIB/IV non-small cell lung cancer: Hoosier Oncology Group LUN06-116. J Thorac Oncol 2010;5:1815-20. CrossRef

9. Shen X, Denittis A, Werner-Wasik M, Axelrod R, Gilman P, Meyer T, et al. Phase i study of 'dose-dense' pemetrexed plus carboplatin/radiotherapy for locally advanced non-small cell lung carcinoma. Radiat Oncol 2011;6:17. CrossRef

10. Aggarwal V, Williams MD, Beath SV. Gastrointestinal problems in the immunosuppressed patient. Arch Dis Child 1998;78:5-8. CrossRef

11. Chao TC, Wang CS, Chen MF. Gastroduodenal perforation in cancer patients. Hepatogastroenterology 1999;46:2878-81.

12. Hussain AA, Abro AH, Siddiqui FG, Memon AA. Prevalence of helicobacter pylori infection in patients with perforated peptic ulcer. JLUMHS 2012;11:172-5.

\section{OLGU SUNUMU - ÖZET}

\section{Üçlü gastrik peptik ülser perforasyonu}

\section{Dr. Milan Radojkovic, ${ }^{1}$ Dr. Suncica Mihajlovic, ${ }^{2}$ Dr. Miroslav Stojanovic, ${ }^{1}$ Dr. Goran Stanojevic, ${ }^{1}$ Dr. Zoran Damnjanovic ${ }^{3}$}

${ }^{1}$ Nis Üniversitesi Tıp Fakültesi, Cerrahi Anabilim Dalı, Nis, Sırbistan

${ }^{2}$ Nis Klinik Merkezi, Cerrahi Kliniği, Nis, Sırbistan

${ }^{3}$ Nis Klinik Merkezi, Vasküler Cerrahi Kliniği, Nis, Sırbistan

İleri veya metastatik kanser hastalarının beslenme, metabolizma ve bağışılık durumları risk altındadır. Buna rağmen kanser hastalarında gastroduodenal perforasyon hakkında az miktarda bilgi mevcuttur. Bu yazıda, 4I yaşındaki evre IV yinelenen larenks kanseri olup homeopatik antikanser tedavisi gören ve cerrahi onarım gerektiren üç adet peptik perforasyonu olan bir kadın hastayı sunmaktayız. Üçlü gastrik peptik ülser perforasyonu nadir görülen olağandışı bir komplikasyondur. Hastaların kendi kendilerine etkinlik ve toksisitesine ilişkin kanıtlara dayalı veriler olmayan homeopatik kanser ilaçlarını kullanmaktan kuvvetle vazgeçirmek gerekir.

Anahtar sözcükler: Peptik ülser; perforasyon.

Ulus Travma Acil Cerrahi Derg 2016;22(2):192-194 doi: 10.5505/tjtes.2015.34202 